\title{
The Actual Cost Price in Sale of Murabahah
}

\author{
Ibrahim Nuhu Tahir
}

\begin{abstract}
This paper critically analyses business transactions that involve product costing methods that have been controversial in the past and have continued to be so in the present. An important factor is the advancement of modern technology which has brought about new activities and responsibilities which emerge on a daily basis. The controversy is regarding a sale known to economists and Muslim jurists as the sale of Murabahah. The analysis in this paper addresses the cost price which the mark-up or profit will be based on. This cost price is the most important pillar in this contract. The scholars categorized what can or cannot be considered as the cost into three categories which the paper will address as category 1, 2 and 3: In category 1 the jurists agree by consensus that it should be included in the cost, in category 2 they agree by consensus that it should be excluded from the cost price where they all agree with it to be excluded, and in category 3 where controversy lies. The analysis in this paper focuses on the last category and aims to clear the controversy. The differing opinions are critically assessed using the primary sources of knowledge in Islam as well as sound logical reasoning. The paper concludes with a clear stand towards those doubtful affairs in relation to the cost price of the item to be sold on Murabahah basis. The paper then outlines recommendations on how Islamic Banks can utilize and benefit from these types of businesses. Insha Allah their implementation will facilitate achieving success in the Islamic banking system in the future.
\end{abstract}

Index Terms-Murabahah, ribh, musawamah, cost price, mark up.

\section{INTRODUCTION}

One of the great blessings of Allah upon His creation is that He made sale contracts and business dealings lawful and permissible. Qur'an says:

"But Allah has permitted trade and forbidden usury" (Surah al-Baqarah, 275) [1].

Trading is halaal in Islam; the general ruling says that every type of business is halaal unless otherwise stated. This places ease in man's daily life as Islam has not put business dealings and transactions on a tight leash. Islam only negates dealings that involve any of the elements it has prohibited such as: usury, gharar (uncertainty), gambling and oppression. In addition, Islam does not introduce new businesses to solve modern problems. On the contrary what it does is to approve dealings that were already being practiced culturally by people. Modifications are made if those practices violate any part of Shari'ah. Imam ibn Rushd said: "the scholars unanimously agreed that sale is divided into two categories, Musawamah (bargain sale) and Murabahah"

Manuscript received December 8, 2013; revised February 23, 2015.

Ibrahim Nuhu Tahir is with the Kulliyyah of Economic and Management Science, Department of Economic, IIUM, Selangor, Malaysia (e-mail: ibrahimnuhu@iium.edu.my).
[2]. The sale of musawamah is normally practiced whereby the seller and buyer negotiate the selling price. The article will focus on the other category, Murabahah. A definition of this category will be given and its ruling according to Shari'ah. The article will then discuss the actual cost encountered in this type of transaction. This calculation of the actual cost price is where there is no consensus among the scholars leading to a controversy. It will end with a conclusion and recommendations.

\section{DEFINITION OF MURABAHAH}

The word Murabahah is derived originally from the word Ribh which literally means profit [3].

According to the definition given to it by the fuqaha' (the Fiqh jurists), the word Murabahah usually refers to a sale of a commodity for its cost price plus a specified mark-up or profit agreed upon by the contracting parties [4]. Thus, $\mathrm{Mu}$ rabahah is the resale of something at some profit added on to the cost price that the seller paid to acquire or complete the good. The process of this transaction is that the seller has to reveal that cost or price of the good upon which the agreement on a profit will then be based. It is important to note that the sale of Murabahah is a trust transaction because the seller is entrusted by the buyer to be honest in revealing the actual cost price without any form of cheating [5]. If the seller in a murabahah transaction is found guilty of any form of deception or cheating, the buyer is given the full right to choose whether to proceed or cancel the contract provided the property has not been destroyed or damaged by the buyer.

Forming the Murabahah price:

$$
\begin{gathered}
\text { Actual Cost Price }(\mathrm{ACp})+\text { Mark-up Price }(\mathrm{Mp})=\text { Agreed } \\
\text { Murabahah Price }(\mathrm{Mbp}) \\
\mathrm{ACp}+\mathrm{Mp}=\mathrm{Mbp}
\end{gathered}
$$

\section{RULING}

As for the ruling of this type of sale, its legality is extracted from the generality of the saying of Allah in the Qur'an:

"O you who believe! Eat not up your property among yourselves unjustly except it be a trade amongst you, by mutual consent. And do not kill yourselves (nor kill one another). Surely, Allah is Most Merciful to you" (Qur'an, Surah al-Nisa', 29).

This is in addition to what was previously mentioned about the legality of sale in general.

"But Allah has permitted trade and forbidden usury" $(2: 275)$. 
The above verse in its meaning includes all kinds of business dealings and trade because the word Tijarah or al-bay' mentioned in the two verses is general. It was also practiced by the companions of the Prophet (sallallahu alaihi wasallam). It has been reported in Sunan al-Baihaqi that Ali ibn Abi Talib brought a piece of cloth and said, "I bought it with five Dirhams, therefore whoever can give me a profit of one dirham on top of the cost price I will sell it to him" [6] This shows without doubt that the transaction is permissible in Islam.

\section{The Actual Cost Price}

It has been previously stated that Imam ibn Rushd said: "the scholars unanimously agreed that sale is divided into two categories, Musawamah (bargain sale) and Murabahah" [1]. This unanimity is with regard to the types. However, when it comes to the details on how the transaction or sale of Murabahah works, the scholars have not yet reached an agreement in some issues. They disagree on the elements that make up the actual cost price and also on the action to be taken when the seller is dishonest in the revelation of the actual cost price.

The first issue is about what can be considered as the cost price. In this regard the scholars have divided the affairs and services in the sale of Murabahah into three categories:

- Services that are considered as part of the cost price and they have an impact or share in the profit, which means that their existence affects the profit. For example, the raw materials needed to produce a final good plus the labor needed to convert it into a product.

$$
\mathrm{ACp}=\text { Cost of raw materials + labor cost }
$$

- Services that are considered as part of the cost, these are the things that the seller cannot do himself and do not have an impact or share in the profit. For example, the cost of sourcing goods from a supplier and bringing them to the market place where the sale will be made to the customer.

$\mathrm{ACp}=$ Cost of raw materials + Shipping costs + Labor cost

- Services that are not considered as part of the cost and they do not affect the profit. For example, the advertising costs incurred by the producer or seller to market his product [7].

\section{$\mathrm{ACp}=$ Cost of white cloth + Shipping costs + Labor Cost Other costs $=$ Advertising Cost}

The first category is included in the cost price since it is impossible to separate the service from the fabric. For example, the labor it takes to dye a white cloth red when the retailer had purchased the cloth himself has to be included in the cost as this type of service is necessary to make the product. Therefore, whenever the good or fabric is sold after the service, which means after the fabric has been turned into a dress, the cost of the service is obviously included in the actual cost price.

Similarly, the second category can also be included in the cost according to some scholars. They said that this is the norm in the market; the service that a trader cannot perform himself and pays a third party to do it is usually included in the cost of the commodity. For example, if a grocery retailer in Saudi Arabia orders durian from Malaysia he would incur all the costs associated with importing a foreign good. Hence he would have to include the costs in the sales price. This is the norm unless if in addition to the aforementioned costs, the seller promises the buyer to deliver the goods to his place. This would also require him to charge a certain fee for the delivery or he would bundle it with the sales price. Thereafter the seller usually calculates all of the expenses he encountered from the time he bought or signed the agreement to buy a product. He is then able to set a reasonable price that will bring a satisfactory profit. According to this view, the seller does not need to inform the buyer about how the cost price is generated. This opinion is attributed to Imam Abu Hanifah; he said the seller in Murabahah has the right to include any expenses of this nature that he had to encounter in order to bring the goods to the market place [1]. Likewise the money paid for the storage of the goods before he sells them would also be included.

The other opinion says it is not permissible in the sale of Murabahah for the seller to include the above mentioned services in the cost without informing the buyer. According to them it is a form of cheating not to inform the buyer that he came up with the total cost by including the costs of acquiring the good, storing it and getting it to the market. They state that the seller should segregate the actual cost price from other costs even though they were a necessity. This opinion says that to make the sale halaal and valid the seller has to make a clear separation of the actual price and cost of other services and responsibilities that the seller had to incur. This is the opinion of the Imam Abu Thaur [8].

As for the last category there is no doubt that these types of services should not be included in the cost price that the profit will be based on. If the seller wants to add them to the cost price, he has to inform the buyer of all the additional costs. If the buyer allows the inclusion to the cost then the contract can be valid. This is based on the saying of Allah in the Qur'an:

O you who believe! Eat not up your property among yourselves unjustly except it be a trade amongst you, by mutual consent. And do not kill yourselves (nor kill one another). Surely, Allah is Most Merciful to you. [004:029].

It also based on the saying of the Prophet (sallallahu alaihi wasallam):

\section{"Verily sale is constituted by mutual consent [9]".}

As long as honesty and clarity are observed by the seller in particular and the buyer accepted what he was informed, then that transaction should be granted validity. This is because the principle that can be extracted from the previous texts of the Shari'ah is that whenever a transaction takes place based on mutual consent and there is no violation of any of the necessary elements of sale then it is valid. According to the Hanafis the seller can also include this without explanation [10]. But the previous opinion is logically stronger.

\section{A. The Cases of Cheating, Overstating and Understating of the Cost Price}

Since the main subject of this paper is the cost price in a sale of Murabahah, it is thus important to discuss the other part of Murabahah which is controversial. This is the issue 
of cheating or violation of the trust in revealing the actual cost price in the sale of Murabahah. This can either be an increase or decrease of the cost revealed by the seller. In cases where this happens the scholars have differed. The argument is on what action should be taken when the deception or error is detected by any of the two contracting parties.

The first case is when the buyer realizes that the seller did not reveal the true actual cost price and evidence proves that the price he gave him was more than the real cost. Hence the argument is as follows:

Imam Malik and many others are of the opinion that the buyer has two options: to accept the dealing based on the correct cost price or to decline as long as the seller does not make it binding upon him to take the correct cost price, if he does, in this case the buyer has no option. This opinion is shown in Fig. 1. Their evidence is that the buyer agreed to add a profit on the correct cost price not what was revealed by the seller. Therefore if cheating is discovered, the only right the buyer has is to go back to the true original or actual price since the agreement already took place.

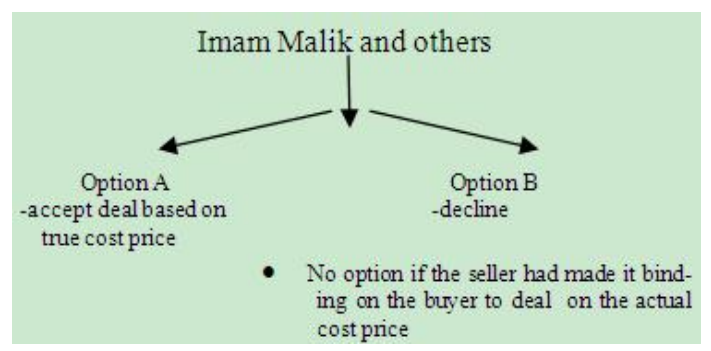

Fig. 1. Case: Buyer detects over-pricing while the product is in existence. Opinion of Imam Malik and others.

Imam Abu Hanifah and Zufar, held the view that the buyer has the right to continue or to decline the transaction without any restriction. Their evidence is that Shari'ah has already approved the existence of option in sale whenever one of the two contracting parties has been deceived or cheated by the other. They said that when the seller fabricated the actual cost price then it is the same as the normal cheating that necessitates absolute option given to the buyer by the Shari'ah, therefore he exercises it here as well. Fig. 2 is an illustration of their opinion.

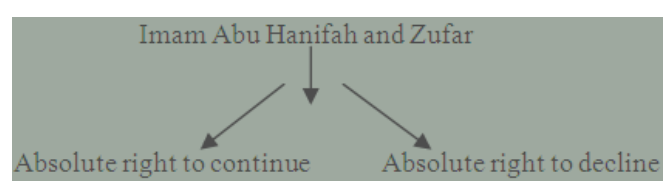

Fig. 2. Case: Buyer detects over-pricing while the product is in existence. Opinion of Abu Hanifah and Zufar.

Imam al-Shafi' was reported to have two opinions; one narration is similar to that of Imam Malik while the other is said to be the same as Imam Abu Hanifah. The aforementioned arguments are with regard to situations where the product still exists. Focus will now be on situations where the product is no longer in existence.

The scholars have also argued in this regard. Imam alShafi' is of the opinion that the buyer is entitled to retain whatever the increase is on top of the correct cost price. Imam Malik on the other hand has a more elaborate opinion that uses the value of the item on the day the buyer received it from the seller as a yardstick. If the value is higher than the said cost price and its profit, for example, Salman bought an item that cost him RM100 and he decided to sell it to Ahmad using Murabahah but he lied to him and told him he bought it for RM150 and thus adding RM50. They thus agreed on RM200. If the buyer detected the cheating after the item has been used, expired or destroyed, we look at the value of the item at the moment he received it. If the value is less than the actual cost price plus its share of the profit on the claimed cost incurred by the seller, the buyer has the right to take back the excess.

The method used to calculate the share of the Murabahah price that the buyer should be reimbursed is as follows. The profit they had agreed on by Murabahah is used to divide the claimed cost. For example, the claimed RM150 would be divided into three 50s. The 50 from Murabahah is then divided into 3 and the quotient is added to each fifty as the profit. One 50 and its profit, in this case 16.70, is then removed, so the buyer does not have to pay it and he pays the remainder. In the case where the value is more than the actual cost price on the day the product is taken possession of, we look at whether it is more or less than the Murabahah price which in this case is RM200. If the value is more than the Murabahah price, the seller has to forfeit the extra and take only the agreed price. If the value is less than the $M u$ rabahah price, the seller has to return the difference between the value and the Murabahah price to the buyer (See [1]).

Value of item on the day of collection in relation to actual cost price.

$$
\begin{gathered}
\text { Actual Cost Price }+ \text { Mark-up Price }=\text { Agreed Murabahah } \\
\text { Price } \\
\mathrm{ACp}+\mathrm{Mp}=\mathrm{Mbp} \\
\text { RM150 + RM50 }=\mathrm{RM} 200
\end{gathered}
$$

False cost price

RM150

True cost price

RM100

Calculating amount reimbursed to buyer

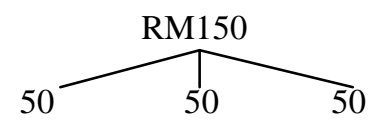

Mark-up Price RM50 /3= 16.70



The buyer pays $(50+16.70) 2=133.40$

RM133.40 is what the seller is entitled to from the transaction.

Value > RM200: seller takes only agreed price.

Value < RM200: seller returns the difference between value and $\mathrm{Mbp}$.

The last case is when the seller realized that he unders- 
tated the purchase cost of the item. He revealed RM 100 as the cost price while the actual cost was RM 150, and he was able to prove that the cost price was RM 150. In this case Imam al-Shafi' said: his claim is unacceptable because it is a lie. Imam Malik held a different perspective in the form of two opinions. One opinion says the buyer has to accept the correct cost price. His other opinion says the buyer has two options: either he pays the value of the item at the time it was received by the buyer or he accepts whatever cost the seller determined to be the correct cost price. The different opinions of the three classical scholars are shown in Table I [10].

TABLE I: CASE: UNDER-STATING THE COST PRICE

\begin{tabular}{|c|c|}
\hline Imam al-Shafi' & Seller's claim is a lie \\
\hline Imam Malik & $\begin{array}{l}\text { Opinion A: buyer must accept the cor- } \\
\text { rect price }\end{array}$ \\
\hline Imam Malik & $\begin{array}{l}\text { Opinion B: can accept the correct price } \\
\text { or takes the value of the good at the time } \\
\text { of collection. }\end{array}$ \\
\hline
\end{tabular}

\section{CONCLUSION}

From what has been mentioned it can be concluded that the cost price can be classified into three categories: in the first category we have services that are automatically included in the cost price and they have a share in the profit. The issue in this type is very clear; the seller does not need to explain any details about the cost price. This is because the sale of Murabahah in this regard is on the piece of cloth and all the services that are necessary to convert it into a useful product. The second category is about the services that are included in the cost price but they have no share in the profit. For the seller to include them in the profit share, he has to inform the buyer about that in details. The last category is about those services that can neither be included in the cost price and nor do they have a share in the profit. If the seller wants to include these types of services it depends on the acceptance of the buyer.

In order to avoid the controversy in the last two categories, the seller should explain everything to the buyer in detail. The Prophet (sallallahu alaihi wasallam) said:

"The two contracting parties have the right to keep or to return the goods as long as they have not parted or till they part; if they exercise honesty by speaking the truth and describing the defects and quality (of the goods), then they will be blessed in their transaction. But if they told lies and hid the defects (of the goods) then the blessing of their transaction will be lost [11].

Finally it is noted that the sale of Murabahah is one of the halaal alternatives the Islamic Banks have. Although there are some controversies on the way the Islamic Banks are utilizing the sale of murabahah, there is a better way. The main problem arises when it comes to the issue of ownership before the agreement with the Bank. The Bank should not sign any contract with any third party before it has complete ownership of the product. The Prophet (sallallahu alaihi wasallam) said

\section{"Do not sell what you do not possess [12]".}

If this condition and its implications are fully observed and implemented, majority of the problems faced by the banks will be solved. In order to achieve this ultimate goal, there is a strong need of qualitative research on how Islamic Banks can gain the freedom they need to possess complete ownership. There is always a way out which can easily be discovered through a qualitative research. This is the directive by the writer for future research in this regard.

\section{REFERENCES}

[1] M. T. D. Al-Hilali and M. Khan, The Noble Qur'an, English Translation of the Meaning and Commentary, Saudi Arabia: King Fahd complex for the printing of the Holy Qur'an.

[2] A. Walid and M. A. M. A. Rushd, The Jurist's Primer (Bidayah alMujtahid wa Nihayah Al-Muqtasid), Beirut: Mu'assasah al-Risalah, 2006, pp. 633-635.

[3] Y. Saleem, Islamic Commercial Law, Singapore: John Wiley \& Sons, 2013, p. 35.

[4] I. Qudamah and A. A. M. Ahmad, The Sufficient (Al-Mughni), Beirut: Dar al-Fikr, vol. 4, no. 380, p. 1404.

[5] M. A. A. A. Samarqandi, The Gift for the Jurists (Tuhfah al-Fuqaha'), Beirut: Dar al-Kutub al- Ilmiyyah, 1994, p. 106.

[6] A. Baihaqi and A. H. Aliyyu. The Great Prophetic Traditions. (AlSunan Al-Kubra). Makkah: Dar al- Baz, 1994, p. 330

[7] M. A. M. A. Rushd, The Jurist's Primer (Bidayah al-Mujtahid wa nihayah al-Muqtasid), Beirut: Mu'assasah al-Risalah, 2006, pp. 633635 .

[8] A. B. M. A. Al-kasani, An Excellent Organisation of Islamic Jurisprudence (Bada'i al-Sana'i' fi Tartib al-Shara'i'), Beirut: Dar al-Kutub al-Ilmiyyah, 1986, p. 223.

[9] M. M. Y. Al-Qazwini, The Prophetic Traditions (Sunan Ibn Majah), Halab: Dar Ihya' al-Kutub al-Arabiyyah, ch.18, p. 737.

[10] M. Anas. The Great Compilation Narrated by Sahnun Al-Mudawanah al-Kubr, (Riwayat Sahnun), Beirut: Dar Alam al-Kutub, vol. 5, pp. 69-70, 2003

[11] A. Bukhari and M. Isma'il, The Authentic Prophetic Traditions (Sahih Al-Bukhari), Beirut: Dar Al-Fikr, ch. 44, p. 743, 1922.

[12] A. Dawud and S. A. Al-sijistaanee, Prophetic Traditions (Sunan Abi Dawud), Beirut: Dar Al-Fikr, ch. 34, pp. 302, 1969.

Ibrahim Nuhu Tahir was born in Zaria, Nigeria on April 19, 1977. The author graduated with B.A degree (first class of honours) in Shari'ah and Islamic studies in the Kulliyyah of Shari'ah in the International Islamic University of Al'Madinah Al'Munawwarah and a postgraduate diploma (first class of honours) in islamic law and islamic political science from the same university. He then proceeded to earn a masters in shariah and civil laws from the International Islamic University of Malaysia. Thereafter he obtained his Ph.d in Shari'ah and civil laws from the same university where he now works as assistant professor in the Kulliyyah of Economics and Management Sciences in the Department of Economics. 